\title{
EVALUATION OF MUCUNA PRURIENS SEED EXTRACT FOR ITS ACUTE ORAL TOXICITY IN ALBINO RATS
}

\author{
GANGADHARA SWAMY ${ }^{1}$, SURESH R RAO ${ }^{1 *}$, RAJENDRA HOLLA ${ }^{2}$ \\ ${ }^{1}$ Department of Anatomy, Subbaiah Institute of Medical Sciences and Research Center, Shivamogga, Karnataka, India. ${ }^{2}$ Department of \\ Pharmacology, K. S. Hegde Medical Academy, Mangalore, Karnataka, India. Email: s4chavan@yahoo.co.in
}

Received: 14 September 2018, Revised and Accepted: 10 November 2018

\section{ABSTRACT}

Objectives: The present study was carried out to evaluate the hydroalcoholic extract of Mucuna pruriens (HAMP) seeds for its acute oral toxicity in albino rats.

Methods: Acute oral toxicity of MP seed extract was assessed in albino rats with three different doses of the extract with 175,550 , and 2000 mg/ kg body weight. Body weight, mortality, and clinical signs were recorded on 0 (before administration), $7^{\text {th }}$, and $14^{\text {th }}$ days. Rats were sacrificed after day 14 and observed for any histological changes in the brain, heart, liver, and kidney tissues. Rats were normal up to $1 \mathrm{~h}$ and exhibited dullness and piloerection after $1 \mathrm{~h}$ which continued up to $2-4 \mathrm{~h}$ of observation period on day 0 of administration. All animals appeared normal from day 1 to throughout the experimental procedure.

Results: No significant changes in the histological structure of the liver, kidney, and heart were noticed except mild congestion and hydropic changes only in liver tissue seen for $2000 \mathrm{mg} / \mathrm{kg}$ body weight of HAMP seeds. The seed extract of MP is non-toxic to rats and did not show any mortality nor the behavioral changes. In addition, it showed an increase in the body weight with the administration up to $2000 \mathrm{mg} / \mathrm{kg}$ body weight.

Conclusion: MP seed extract signified as neurosuppressant, and the drug can be used in the treatment of neurological disorders characterized by hyperactivity of the neurons. The present data could provide adequate confirmation of the safety of MP for further experimental studies on a standardized formulation of the seeds extract.

Keywords: Mucuna pruriens seeds, Acute oral toxicity, OECD guidelines 425, Median lethal dose, Neurosuppressant.

(c) 2019 The Authors. Published by Innovare Academic Sciences Pvt Ltd. This is an open access article under the CC BY license (http://creativecommons. org/licenses/by/4. 0/) DOI: http://dx.doi.org/10.22159/ajpcr.2019.v12i2.29750

\section{INTRODUCTION}

Mucuna pruriens (MP) commonly called velvet bean is a tropical legume indigenous tree to Africa and tropical Asia. As it is one of the best sources of protein content in many African countries, it is used as food for humans and also the animal feed [1]. MP seed pods are covered with hairs which are rich in 5-Hydroxy tryptamine (5-HT) \& if they come in touch with skin that causes severe itching [2,3]. Its seeds contain many micronutrients including amino acids, zinc, selenium, carbohydrates [4], and various plant alkaloids [5]. In addition to these ingredients, the seeds' main ingredient is L-DOPA [6]. In Ayurveda, Parkinson's disease (PD) is referred as Kampavata, which is one among eighty Vathaja diseases (Astha Mahagathavatarogas), and there are a sufficient number of references explaining in detail for the PD for its cause, prognosis, and its treatment using many medicinal formulations with main ingredient as the MP seeds [7,8-10]. Numerous research works have been proven that MP seeds contain L-DOPA [1,11-13], which is a just precursor to the neurotransmitter dopamine during its synthesis, which is found in the nigrostriatal pathway of the basal nuclei of the midbrain [14].

According to Akhtar et al., the ethanolic extract of seeds of MP possesses anti-cataleptic and antiepileptic effect in albino rats, and dopamine and serotonin may have a role in such activity [15]. Apart from this, it is reported from this plant that it is also having antiurolithiatic [14], antidiabetic [15-17], anticancer, and antioxidant properties [18]. However, if consumed in large quantities of crude MP seeds as food, it is poisonous to mammals $[19,20]$. This indicates that there is some toxicity related to MP.

As per the OECD guidelines before the clinical trial on humans for any drug, it should be tested on animals to define its median oral toxicity (lethal dose $\left[\mathrm{LD}_{50}\right]$ ) values and its effective/therapeutic dose. The name $\mathrm{LD}_{50}$ is an abbreviation for "median $\mathrm{LD}_{50} 50 \%$." It is the amount of the substance required (usually per body weight) to kill $50 \%$ of the test population. $\mathrm{LD}_{50}$ is the amount of a drug, given oral all at once, which causes the death in $>50 \%$ (one half) of experimental animals in a group [21]. The $\mathrm{LD}_{50}$ is one way to measure the short-term poisoning potential (acute toxicity) of a material. Rats and mice are most routinely used for the experiment by the toxicologist. It is usually expressed as the amount of chemical administered (e.g., mg) per $100 \mathrm{~g}$ (for smaller animals) or per kilogram (for bigger test subjects) of the body weight of the test animal. The $\mathrm{LD}_{50}$ can be found for any route of entry or administration, but dermal (applied to the skin) and oral (given by the mouth) administration methods are the most common [22-24].

\section{MATERIALS AND METHODS}

\section{Plant material}

The seeds of MP were collected from the Sri Dharmastala Ayurveda Medical College and Research Center, Udupi, Karnataka, India. The plant material was stored in ambient conditions for further study.

\section{Preparation of extract}

The MP seeds were dried in shade and powdered in our research laboratory with the help of pulverizer. The hydroalcoholic extract of MP (HAMP) seeds were prepared by soaking $500 \mathrm{~g}$ of powdered seeds of MP in 2 liters of $50 \%$ ethanol and $50 \%$ cold distilled water for $24 \mathrm{~h}$, filtered, and concentrated by evaporating on water bath till free from water. The extract has been stored in airtight container under normal temperature [10].

\section{Experimental animals}

This study was performed in a CPCSEA approved laboratory under registration number 115/1999/CPCSEA following all ethical practices 
as laid down in the guidelines for animal care. This study has been approved by the Institutional Animal Ethics Committee (IAEC) KSHEMA/IAEC/08/2017. The study procedure described in this study met the requirements of OECD guidelines for testing of chemicals, number 425, "acute oral toxicity-acute toxic class method."

Female albino rats (9-11 weeks, weighing between 200 and 250 g) were used for the experiment. All animals were maintained under standard laboratory conditions, with a constant $12 \mathrm{~h}$ light/dark cycle and controlled temperature $\left(25 \pm 2^{\circ} \mathrm{C}\right)$ with access to drinking water and pellet diet ad libitum [25].

\section{Chemicals}

The solvents and chemicals required carboxymethyl cellulose (CMC) as a suspending agent and distilled water as a solvent.

\section{Methodology}

Female albino rats were selected based on their days of acclimatization. The rats were divided into three groups, namely Group A, Group B, and Group $C$, with each group having six rats $(n=6)$. They were kept fasting for overnight (but with the free access to water). On the test day 0 , the rats in each group had received a single dose of the plant extract by oral gavage method dosages at 175, 550, and $2000 \mathrm{mg} / \mathrm{kg}$ body weight, respectively. Approximately after $17 \mathrm{~h}$ of fasting but with free access to water, the animals were continued with proper diet [5-8].
Calculation for the preparation of the stock solution

- Group A: $175 \mathrm{mg}$ of MP is mixed with $50 \mathrm{mg}$ of CMC and the mixture is dissolved in $10 \mathrm{ml}$ distilled water to get the concentration of $17.5 \mathrm{mg} / \mathrm{ml}$.

- Group B: $550 \mathrm{mg}$ of MP is mixed with $50 \mathrm{mg}$ of CMC and the mixture is dissolved in $10 \mathrm{ml}$ distilled water to get the concentration of $55 \mathrm{mg} / \mathrm{ml}$.

- Group C: $2000 \mathrm{mg}$ of MP is mixed with $50 \mathrm{mg}$ of CMC and the mixture is dissolved in $10 \mathrm{ml}$ distilled water to get the concentration of $200 \mathrm{mg} / \mathrm{ml}$.

The animals were observed for the acclimatization before the oral gavage of the drug and also daily during the test period for clinical signs such as sedative effect, decreased locomotor activity, breathlessness, and mortality/viability and were recorded during first $30 \mathrm{~min}$ and at approximately with the duration of $1,2,3$, and $4 \mathrm{~h}$ after administration of test drug on day 0 and daily twice during days 1-14 [24,25]. Body weights of all the rats were recorded on test day 0 (before administration) and also on test days 7 and 14 .

At the end of the $14^{\text {th }}$ day of observation period, the animals were deeply anesthetized with ether. All the animals were observed for any gross/macroscopic pathological changes, and the brain, liver, heart, and kidneys from the representative groups of animals were removed and processed for the histological studies as follows [26].

Table 1a: Mortality and clinical signs observed with Mucuna pruriens seed extract (175 mg/kg body weight) in rats over a period of 14 days

\begin{tabular}{|c|c|c|c|c|c|c|c|c|c|c|c|c|c|c|c|c|c|c|c|}
\hline \multirow[t]{3}{*}{ Animal ID No. } & \multicolumn{19}{|c|}{ Test days } \\
\hline & \multicolumn{5}{|l|}{$\mathbf{0}^{*}$} & \multirow[t]{2}{*}{1} & \multirow[t]{2}{*}{2} & \multirow[t]{2}{*}{3} & \multirow[t]{2}{*}{4} & \multirow[t]{2}{*}{5} & \multirow[t]{2}{*}{6} & \multirow[t]{2}{*}{7} & \multirow[t]{2}{*}{8} & \multirow[t]{2}{*}{9} & \multirow[t]{2}{*}{10} & \multirow[t]{2}{*}{11} & \multirow[t]{2}{*}{12} & \multirow[t]{2}{*}{13} & \multirow[t]{2}{*}{14} \\
\hline & $30 \mathrm{~min}$ & $1 \mathrm{~h}$ & $2 \mathrm{~h}$ & $3 \mathrm{~h}$ & $4 \mathrm{~h}$ & & & & & & & & & & & & & & \\
\hline \multirow[t]{2}{*}{ A1 } & $\mathrm{N}$ & $\mathrm{D}$ & $\mathrm{D}$ & $\mathrm{D}$ & $\mathrm{D}$ & D & $\mathrm{N}$ & $\mathrm{N}$ & $\mathrm{N}$ & $\mathrm{N}$ & $\mathrm{N}$ & $\mathrm{N}$ & $\mathrm{N}$ & $\mathrm{N}$ & $\mathrm{N}$ & $\mathrm{N}$ & $\mathrm{N}$ & $\mathrm{N}$ & $\mathrm{N}$ \\
\hline & & & $\mathrm{P}$ & $\mathrm{P}$ & $\mathrm{P}$ & & & & & & & & & & & & & & \\
\hline \multirow[t]{2}{*}{ A2 } & $\mathrm{N}$ & $\mathrm{D}$ & $\mathrm{D}$ & D & $\mathrm{D}$ & $\mathrm{N}$ & $\mathrm{N}$ & $\mathrm{N}$ & $\mathrm{N}$ & $\mathrm{N}$ & $\mathrm{N}$ & $\mathrm{N}$ & $\mathrm{N}$ & $\mathrm{N}$ & $\mathrm{N}$ & $\mathrm{N}$ & $\mathrm{N}$ & $\mathrm{N}$ & $\mathrm{N}$ \\
\hline & & & $\mathrm{P}$ & $\mathrm{P}$ & $\mathrm{P}$ & & & & & & & & & & & & & & \\
\hline \multirow[t]{2}{*}{ A3 } & $\mathrm{N}$ & $\mathrm{D}$ & $\mathrm{D}$ & D & $\mathrm{D}$ & $\mathrm{N}$ & $\mathrm{N}$ & $\mathrm{N}$ & $\mathrm{N}$ & $\mathrm{N}$ & $\mathrm{N}$ & $\mathrm{N}$ & $\mathrm{N}$ & $\mathrm{N}$ & $\mathrm{N}$ & $\mathrm{N}$ & $\mathrm{N}$ & $\mathrm{N}$ & $\mathrm{N}$ \\
\hline & & $\mathrm{P}$ & $\mathrm{P}$ & $\mathrm{P}$ & $\mathrm{P}$ & & & & & & & & & & & & & & \\
\hline \multirow[t]{2}{*}{$\mathrm{A} 4$} & $\mathrm{~N}$ & $\mathrm{D}$ & $\mathrm{D}$ & D & D & $\mathrm{N}$ & $\mathrm{N}$ & $\mathrm{N}$ & $\mathrm{N}$ & $\mathrm{N}$ & $\mathrm{N}$ & $\mathrm{N}$ & $\mathrm{N}$ & $\mathrm{N}$ & $\mathrm{N}$ & $\mathrm{N}$ & $\mathrm{N}$ & $\mathrm{N}$ & $\mathrm{N}$ \\
\hline & & $\mathrm{P}$ & $\mathrm{P}$ & $\mathrm{P}$ & $\mathrm{P}$ & & & & & & & & & & & & & & \\
\hline \multirow[t]{2}{*}{ A5 } & $\mathrm{N}$ & $\mathrm{D}$ & $\mathrm{D}$ & D & $\mathrm{D}$ & $\mathrm{N}$ & $\mathrm{N}$ & $\mathrm{N}$ & $\mathrm{N}$ & $\mathrm{N}$ & $\mathrm{N}$ & $\mathrm{N}$ & $\mathrm{N}$ & $\mathrm{N}$ & $\mathrm{N}$ & $\mathrm{N}$ & $\mathrm{N}$ & $\mathrm{N}$ & $\mathrm{N}$ \\
\hline & & $\mathrm{P}$ & $\mathrm{P}$ & $\mathrm{P}$ & $\mathrm{P}$ & & & & & & & & & & & & & & \\
\hline \multirow[t]{2}{*}{ A6 } & $\mathrm{N}$ & $\mathrm{D}$ & D & D & $\mathrm{D}$ & D & $\mathrm{N}$ & $\mathrm{N}$ & $\mathrm{N}$ & $\mathrm{N}$ & $\mathrm{N}$ & $\mathrm{N}$ & $\mathrm{N}$ & $\mathrm{N}$ & $\mathrm{N}$ & $\mathrm{N}$ & $\mathrm{N}$ & $\mathrm{N}$ & $\mathrm{N}$ \\
\hline & & & $\mathrm{P}$ & $\mathrm{P}$ & $\mathrm{P}$ & & & & & & & & & & & & & & \\
\hline
\end{tabular}

N: Normal, D: Dullness, P: Piloerection

Table 1b: Mortality and clinical signs observed with Mucuna pruriens seed extract (550 mg/Kg body weight) in rats over a period of 14 days

\begin{tabular}{|c|c|c|c|c|c|c|c|c|c|c|c|c|c|c|c|c|c|c|c|}
\hline \multirow[t]{3}{*}{ Animal ID No. } & \multicolumn{19}{|c|}{ Test days } \\
\hline & \multicolumn{5}{|l|}{$\mathbf{0}^{*}$} & \multirow[t]{2}{*}{1} & \multirow[t]{2}{*}{2} & \multirow[t]{2}{*}{3} & \multirow[t]{2}{*}{4} & \multirow[t]{2}{*}{5} & \multirow[t]{2}{*}{6} & \multirow[t]{2}{*}{7} & \multirow[t]{2}{*}{8} & \multirow[t]{2}{*}{9} & \multirow[t]{2}{*}{10} & \multirow[t]{2}{*}{11} & \multirow[t]{2}{*}{12} & \multirow[t]{2}{*}{13} & \multirow[t]{2}{*}{14} \\
\hline & $30 \mathrm{~min}$ & $1 \mathrm{~h}$ & $2 \mathrm{~h}$ & $3 \mathrm{~h}$ & $4 h$ & & & & & & & & & & & & & & \\
\hline \multirow[t]{2}{*}{ B1 } & $\mathrm{N}$ & D & D & D & D & $\mathrm{N}$ & $\mathrm{N}$ & $\mathrm{N}$ & $\mathrm{N}$ & $\mathrm{N}$ & $\mathrm{N}$ & $\mathrm{N}$ & $\mathrm{N}$ & $\mathrm{N}$ & $\mathrm{N}$ & $\mathrm{N}$ & $\mathrm{N}$ & $\mathrm{N}$ & $\mathrm{N}$ \\
\hline & & $\mathrm{P}$ & $\mathrm{P}$ & $\mathrm{P}$ & $\mathrm{P}$ & & & & & & & & & & & & & & \\
\hline \multirow[t]{2}{*}{ B2 } & $\mathrm{N}$ & D & $\mathrm{D}$ & $\mathrm{D}$ & $\mathrm{D}$ & $\mathrm{N}$ & $\mathrm{N}$ & $\mathrm{N}$ & $\mathrm{N}$ & $\mathrm{N}$ & $\mathrm{N}$ & $\mathrm{N}$ & $\mathrm{N}$ & $\mathrm{N}$ & $\mathrm{N}$ & $\mathrm{N}$ & $\mathrm{N}$ & $\mathrm{N}$ & $\mathrm{N}$ \\
\hline & & $\mathrm{P}$ & $\mathrm{P}$ & $\mathrm{P}$ & $\mathrm{P}$ & & & & & & & & & & & & & & \\
\hline \multirow[t]{2}{*}{ B3 } & $\mathrm{N}$ & D & $\mathrm{D}$ & $\mathrm{D}$ & $\mathrm{D}$ & $\mathrm{N}$ & $\mathrm{N}$ & $\mathrm{N}$ & $\mathrm{N}$ & $\mathrm{N}$ & $\mathrm{N}$ & $\mathrm{N}$ & $\mathrm{N}$ & $\mathrm{N}$ & $\mathrm{N}$ & $\mathrm{N}$ & $\mathrm{N}$ & $\mathrm{N}$ & $\mathrm{N}$ \\
\hline & & $\mathrm{P}$ & $\mathrm{P}$ & $\mathrm{P}$ & $\mathrm{P}$ & & & & & & & & & & & & & & \\
\hline \multirow[t]{2}{*}{ B4 } & $\mathrm{N}$ & D & D & D & D & $\mathrm{N}$ & $\mathrm{N}$ & $\mathrm{N}$ & $\mathrm{N}$ & $\mathrm{N}$ & $\mathrm{N}$ & $\mathrm{N}$ & $\mathrm{N}$ & $\mathrm{N}$ & $\mathrm{N}$ & $\mathrm{N}$ & $\mathrm{N}$ & $\mathrm{N}$ & $\mathrm{N}$ \\
\hline & & & $\mathrm{P}$ & $\mathrm{P}$ & $\mathrm{P}$ & & & & & & & & & & & & & & \\
\hline \multirow[t]{2}{*}{ B5 } & $\mathrm{N}$ & D & $\mathrm{D}$ & $\mathrm{D}$ & $\mathrm{D}$ & $\mathrm{N}$ & $\mathrm{N}$ & $\mathrm{N}$ & $\mathrm{N}$ & $\mathrm{N}$ & $\mathrm{N}$ & $\mathrm{N}$ & $\mathrm{N}$ & $\mathrm{N}$ & $\mathrm{N}$ & $\mathrm{N}$ & $\mathrm{N}$ & $\mathrm{N}$ & $\mathrm{N}$ \\
\hline & & $\mathrm{P}$ & $\mathrm{P}$ & $\mathrm{P}$ & $\mathrm{P}$ & & & & & & & & & & & & & & \\
\hline \multirow[t]{2}{*}{ B6 } & $\mathrm{N}$ & D & $\mathrm{D}$ & $\mathrm{D}$ & $\mathrm{D}$ & $\mathrm{N}$ & $\mathrm{N}$ & $\mathrm{N}$ & $\mathrm{N}$ & $\mathrm{N}$ & $\mathrm{N}$ & $\mathrm{N}$ & $\mathrm{N}$ & $\mathrm{N}$ & $\mathrm{N}$ & $\mathrm{N}$ & $\mathrm{N}$ & $\mathrm{N}$ & $\mathrm{N}$ \\
\hline & & & $\mathrm{P}$ & $\mathrm{P}$ & $\mathrm{P}$ & & & & & & & & & & & & & & \\
\hline
\end{tabular}

N: Normal, D: Dullness, P: Piloerection 
Table 1c: Mortality and clinical signs observed with Mucuna pruriens seed extract ( $2000 \mathrm{mg} / \mathrm{kg}$ body weight) in rats over a period of 14 days

\begin{tabular}{|c|c|c|c|c|c|c|c|c|c|c|c|c|c|c|c|c|c|c|c|}
\hline \multirow[t]{3}{*}{ Animal ID No. } & \multicolumn{19}{|c|}{ Test days } \\
\hline & \multicolumn{5}{|l|}{0} & \multirow[t]{2}{*}{1} & \multirow[t]{2}{*}{2} & \multirow[t]{2}{*}{3} & \multirow[t]{2}{*}{4} & \multirow[t]{2}{*}{5} & \multirow[t]{2}{*}{6} & \multirow[t]{2}{*}{7} & \multirow[t]{2}{*}{8} & \multirow[t]{2}{*}{9} & \multirow[t]{2}{*}{10} & \multirow[t]{2}{*}{11} & \multirow[t]{2}{*}{12} & \multirow[t]{2}{*}{13} & \multirow[t]{2}{*}{14} \\
\hline & $30 \mathrm{~min}$ & $1 \mathrm{~h}$ & $2 \mathrm{~h}$ & $3 \mathrm{~h}$ & $4 \mathrm{~h}$ & & & & & & & & & & & & & & \\
\hline \multirow[t]{2}{*}{$\mathrm{C} 1$} & D & $\mathrm{D}$ & D & D & D & D & $\mathrm{N}$ & $\mathrm{N}$ & $\mathrm{N}$ & $\mathrm{N}$ & $\mathrm{N}$ & $\mathrm{N}$ & $\mathrm{N}$ & $\mathrm{N}$ & $\mathrm{N}$ & $\mathrm{N}$ & $\mathrm{N}$ & $\mathrm{N}$ & $\mathrm{N}$ \\
\hline & & $\mathrm{P}$ & $\mathrm{P}$ & $\mathrm{P}$ & $\mathrm{P}$ & & & & & & & & & & & & & & \\
\hline \multirow[t]{2}{*}{$\mathrm{C} 2$} & D & $\mathrm{D}$ & D & D & D & $\mathrm{N}$ & $\mathrm{N}$ & $\mathrm{N}$ & $\mathrm{N}$ & $\mathrm{N}$ & $\mathrm{N}$ & $\mathrm{N}$ & $\mathrm{N}$ & $\mathrm{N}$ & $\mathrm{N}$ & $\mathrm{N}$ & $\mathrm{N}$ & $\mathrm{N}$ & $\mathrm{N}$ \\
\hline & & $\mathrm{P}$ & $\mathrm{P}$ & $\mathrm{P}$ & $\mathrm{P}$ & & & & & & & & & & & & & & \\
\hline \multirow[t]{2}{*}{$\mathrm{C} 3$} & D & D & D & D & D & $\mathrm{N}$ & $\mathrm{N}$ & $\mathrm{N}$ & $\mathrm{N}$ & $\mathrm{N}$ & $\mathrm{N}$ & $\mathrm{N}$ & $\mathrm{N}$ & $\mathrm{N}$ & $\mathrm{N}$ & $\mathrm{N}$ & $\mathrm{N}$ & $\mathrm{N}$ & $\mathrm{N}$ \\
\hline & & $\mathrm{P}$ & $\mathrm{P}$ & $\mathrm{P}$ & & & & & & & & & & & & & & & \\
\hline \multirow[t]{2}{*}{$\mathrm{C} 4$} & D & D & D & D & D & $\mathrm{N}$ & $\mathrm{N}$ & $\mathrm{N}$ & $\mathrm{N}$ & $\mathrm{N}$ & $\mathrm{N}$ & $\mathrm{N}$ & $\mathrm{N}$ & $\mathrm{N}$ & $\mathrm{N}$ & $\mathrm{N}$ & $\mathrm{N}$ & $\mathrm{N}$ & $\mathrm{N}$ \\
\hline & & $\mathrm{P}$ & $\mathrm{P}$ & $\mathrm{P}$ & & & & & & & & & & & & & & & \\
\hline \multirow[t]{2}{*}{$\mathrm{C} 5$} & D & D & D & $\mathrm{D}$ & $\mathrm{D}$ & $\mathrm{N}$ & $\mathrm{N}$ & $\mathrm{N}$ & $\mathrm{N}$ & $\mathrm{N}$ & $\mathrm{N}$ & $\mathrm{N}$ & $\mathrm{N}$ & $\mathrm{N}$ & $\mathrm{N}$ & $\mathrm{N}$ & $\mathrm{N}$ & $\mathrm{N}$ & $\mathrm{N}$ \\
\hline & & $\mathrm{P}$ & $\mathrm{P}$ & $\mathrm{P}$ & & & & & & & & & & & & & & & \\
\hline \multirow[t]{2}{*}{ C6 } & $\mathrm{D}$ & $\mathrm{D}$ & $\mathrm{D}$ & $\mathrm{D}$ & $\mathrm{D}$ & D & $\mathrm{N}$ & $\mathrm{N}$ & $\mathrm{N}$ & $\mathrm{N}$ & $\mathrm{N}$ & $\mathrm{N}$ & $\mathrm{N}$ & $\mathrm{N}$ & $\mathrm{N}$ & $\mathrm{N}$ & $\mathrm{N}$ & $\mathrm{N}$ & $\mathrm{N}$ \\
\hline & & & $\mathrm{P}$ & $\mathrm{P}$ & & & & & & & & & & & & & & & \\
\hline
\end{tabular}

N: Normal, D: Dullness, P: Piloerection

Table 2a: Physical observations in experimental rats with Mucuna pruriens seed extract (175 mg/kg body weight) at terminal sacrifice.

\begin{tabular}{ll}
\hline Animal ID No. & Physical observations in experimental rats \\
\hline A1 & No abnormality detected \\
A2 & No abnormality detected \\
A3 & No abnormality detected \\
A4 & No abnormality detected \\
A5 & No abnormality detected \\
A6 & No abnormality detected \\
\hline
\end{tabular}

Table 2b: Physical observations in experimental rats with Mucuna pruriens seed extract (550 mg/kg body weight) at terminal sacrifice

\begin{tabular}{ll}
\hline Animal ID No. & Physical observations in experimental rats \\
\hline B1 & No abnormality detected \\
B2 & No abnormality detected \\
B3 & No abnormality detected \\
B4 & No abnormality detected \\
B5 & No abnormality detected \\
B6 & No abnormality detected \\
\hline
\end{tabular}

Table 2c: Physical observations in experimental rats with Mucuna pruriens seed extract ( $2000 \mathrm{mg} / \mathrm{kg}$ body weight) at terminal sacrifice

\begin{tabular}{ll}
\hline Animal ID No. & Physical observations in experimental rats \\
\hline C1 & No abnormality detected \\
C2 & No abnormality detected \\
C3 & No abnormality detected \\
C4 & No abnormality detected \\
C5 & No abnormality detected \\
C6 & No abnormality detected \\
\hline
\end{tabular}

\section{Procedure}

The animals were deeply anesthetized with ether and fixed on a dissection board, and its chest cavity was opened to expose the heart. About $15 \mathrm{ml}$ of $0.9 \%$ saline was perfused through the left ventricle at the rate of $1 \mathrm{ml} / \mathrm{min}$. This was followed by perfusion with $10 \%$ formalin, about $250 \mathrm{ml} /$ adult rats, at the same rate. The animals were decapitated, and 5-6 mm thick coronal section of the brain with the cerebral cortex, midbrain, liver, kidneys, and heart were removed and

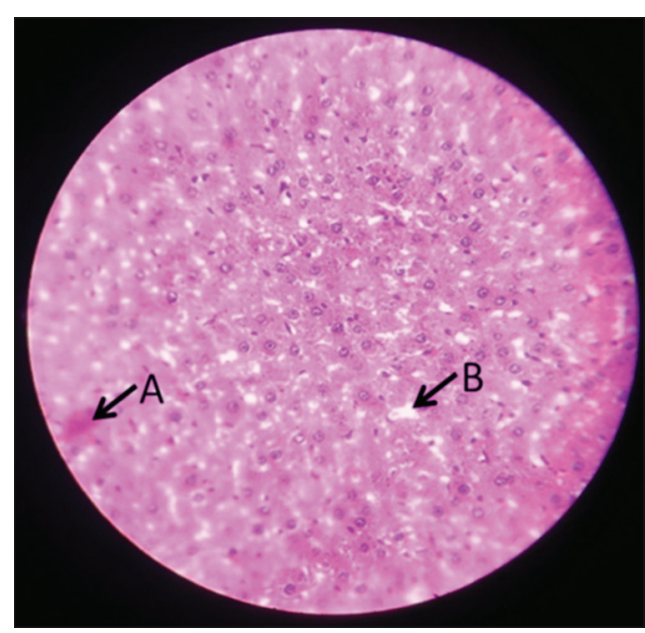

Fig. 1: Histological picture of the liver (magnification, $\times 40$ ) at the dose $2000 \mathrm{mg} / \mathrm{kg}$ body weight of HAMP. Arrow mark A - shows mild congestion and $B$ - shows hydrophic changes

kept in $10 \%$ formalin for $24 \mathrm{~h}$ (post-fixation). Paraffin blocks were made given below.

\section{Statistical analysis}

Statistical analysis is performed using Student's $t$-test and one-way ANOVA where ever it is applicable.

\section{RESULTS AND DISCUSSION}

Oral administration of HAMP at three different doses for 14 days in albino rats did not produce any significant toxicity symptoms in rats, including the highest dose tested at $2000 \mathrm{mg} / \mathrm{kg}$ body weight. No obvious clinical signs were found in any groups at initial $30 \mathrm{~min}$ of observation.

Changes in the clinical symptoms such as dullness and piloerection were noted after $1 \mathrm{~h}$ which continued up to $4 \mathrm{~h}$ of observation period on 0 day. Rats of all the three doses appeared normal and did not show signs of toxicity in their skin, fur, eyes, diarrhea, and behavior from day 1 and continued to remain normal throughout the experimental period (Table 1a-c).

A brief period of dullness on day 0 indicates a possible neurosuppression role of the drug extract. We did not find any significant changes in the mortality rate in any groups exposed to orally administered HAMP Albino rats. 
Table 3: Changes in body weight of experimental rats with Mucuna pruriens seed extract $(175,550$, and $2000 \mathrm{mg} / \mathrm{kg} \mathrm{body} \mathrm{weight)} \mathrm{at} 0,7$, and 14 days

\begin{tabular}{|c|c|c|c|c|}
\hline Groups (mg/kg body weight) & Number of animals (n) & 0 day & $7^{\text {th }}$ day & $14^{\text {th }}$ day \\
\hline 175 & 6 & $226.77 \pm 6.036$ & $240.35 \pm 6.354^{*}$ & $251.00 \pm 6.392^{*}$ \\
\hline 550 & 6 & $205.97 \pm 1.458$ & $214.03 \pm 1.492^{*}$ & $220.55 \pm 1.479 * *$ \\
\hline 2000 & 6 & $212.43 \pm 0.6407$ & $222.01 \pm 1.085^{*}$ & $233.75 \pm 1.917^{* * *}$ \\
\hline
\end{tabular}

Values are expressed as mean \pm SE. *p values were considered significant using one-way ANOVA.*p<0.05, ANOVA significance F=3.761 for $175 \mathrm{mg} / \mathrm{kg}$ body weight,

${ }^{* *} \mathrm{p}<0.01$, ANOVA significance $\mathrm{F}=24.48$ for $550 \mathrm{mg} / \mathrm{kg}$ body weight and ${ }^{* * *} \mathrm{p}<0.001$, ANOVA significance $\mathrm{F}=64.954$ for $2000 \mathrm{mg} / \mathrm{kg}$ body weight

No gross abnormalities were observed in any animals until the terminal sacrifice period (Table 2a-c).

A significant increase in the body weight was observed in all the rats subjected for the study by day 14 as compared to 0 days of the experimental animals (Table 3).

Light microscopic examination of sections of various organs such as the liver, heart, and kidney of the drug-administered groups showed a normal cytoarchitecture and absence of any gross pathological lesions, in all the three groups except mild congestion and hydrophilic changes found in the liver at the dose $2000 \mathrm{mg} / \mathrm{kg}$ body weight of HAMP drugadministered rats when compared with normal (Fig. 1).

Above results indicate that, after oral administration of the HAMP seed extract, rats appeared dull for a brief period (on test day 0 ), after which they became normal throughout the experimental procedure (until 14 days). Interestingly, no mortality was observed in the rats. This temporary dullness indicates a possible role of the neurosuppressive effect of the extract. The above experiment has recorded a lethal dose of the HAMP which is more than $2000 \mathrm{mg} / \mathrm{Kg}$ body weight, and the same values can be practiced for the further studies to define its effective dose and the therapeutic index, so that it can be safely used as a drug in the treatment of neurological disorders characterized by the hyperactivity of neurons. Moreover, it was also observed that all the rats had gained body weight by the end of the experimental procedure. This establishes that the L-DOPAenriched extract of MP is non-cytotoxic to the rats. Based on the results obtained, the $\mathrm{LD}_{50}$ of HAMP after single oral administration to female rats, observed over a period of 14 days, is $>2000 \mathrm{mg} / \mathrm{kg}$ body weight. Sardjono et al. also showed non-toxic effect of MP seed extracts, but it was carried out using ethanol extract, which supports our study [27].

\section{CONCLUSION}

MP seed extract was evaluated for its acute oral toxicity in albino rats. It was found that HAMP at high dosage $(2000 \mathrm{mg} / \mathrm{Kg}$ body weight) was non-toxic to the rats and it too aided in bringing in the body weight. In addition, a brief period of dullness indicates a possible role of the extract in neurosuppression as well. Thus, it can be used safely as a drug in the treatment of neurological disorders characterized by the hyperactivity of neurons. The results of this study also collectively specify that oral administration of HAMP is not connected with any toxicological significant effects and the data could provide satisfactory preclinical evidence of safety to launch a clinical trial on a standardized formulation of the plant extracts. Based on the study, we are able to estimate the $\mathrm{LD}_{50}$ of the test drug, which can be used safely for further experimental studies on the rats, and to calculate its therapeutic dose and also to know it antiParkinsonism effect in rotenone-induced Parkinsonism-diseased rats.

\section{ACKNOWLEDGMENT}

The authors sincerely would like to thank: Sri Darmastala Ayurveda Medical College and Research Center, Udupi, Karnataka, India, for providing plant material for this study; the Management of Subbaiah Institute of Medical Sciences and Research Center, Shivamogga; and the Management of K. S. Hegde medical Academy, Deralakatte, Mangalore.

\section{AUTHORS' CONTRIBUTIONS}

The first author designed and worked on the experiment, the second author collected the review of literature and also planned for the experiment, and the third author helped in planning and statistical analysis of the work. All the three authors equally contributed for the overall study.

\section{CONFLICTS OF INTEREST}

The authors do not have any conflict of interest on the publication of this manuscript.

\section{REFERENCES}

1. Dart RC, Caravati EM, McGuigan MA. Medical Toxicology. $3^{\text {rd }}$ ed. Philadelphia, PA, US: Lippincott Williams and Wilkins; 2004.

2. Rajeshwar Y, Gupta M, Mazumder UK. Antitumor activity and in vivo antioxidant status of Mucuna pruriens (Fabaceae) seeds against Ehrlich ascites carcinoma in Swiss albino mice. Iran J Pharm Ther 2005;4:46-53.

3. Reddy VB, Iuga AO, Shimada SG, LaMotte RH, Lerner EA. Cowhageevoked itch is mediated by a novel cysteine protease: A ligand of protease-activated receptors. J Neurosci 2008;28:4331-5.

4. Guerranti R, Aguiyi JC, Leoncini R, Pagani R, Cinci G, Marinello E. Characterization of the factor responsible for the antisnake activity of Mucuna pruriens seeds. J Prev Med Hyg 1999;40:25-8.

5. Tan NH, Fung SY, Sim SM, Marinello E, Guerranti R, Aguiyi JC, et al. The protective effect of Mucuna pruriens seeds against snake venom poisoning. J Ethnopharmacol 2009;123:356-8.

6. Meenatchisundaram S, Michael A. Antitoxin activity of Mucuna pruriens aqueous extracts against cobra and krait venom by in vivo and in vitro methods. Int J Pharm Tech Res 2010;2:870-4.

7. Daxenbichler ME, Van Etten CH, Earle FR, Tallent WH. 1-Dopa recovery from Mucuna seed. J Agric Food Chem 1972;20:1046-8.

8. Lieu CA, Kunselman AR, Manyam BV, Venkiteswaran K, Subramanian T. A water extract of Mucuna pruriens provides longterm amelioration of parkinsonism with reduced risk for dyskinesias. Parkinsonism Relat Disord 2010;16:458-65.

9. Kulhalli P. Parkinson's disease therapy-an overview. Heritage Heal 1999;98:29-30.

10. Champatisingh D, Sahu PK, Pal A, Nanda GS. Anticataleptic and antiepileptic activity of ethanolic extract of leaves of Mucuna pruriens: A study on role of dopaminergic system in epilepsy in albino rats. Indian J Pharmacol 2011;43:197-9.

11. Siddhuraju P, Becker K. Rapid reversed-phase high performance liquid chromatographic method for the quantification of L-Dopa (L-3, 4-dihydroxyphenylalanine), non-methylated and methylated tetrahydroisoquinoline compounds from Mucuna beans. Food Chem 2001;72:389-94.

12. Misra L, Wagner H. Alkaloidal constituents of Mucuna pruriens seeds. Phytochemistry 2004;65:2565-7.

13. Manyam BV, Dhanasekaran M, Hare TA. Neuroprotective effects of the antiparkinson drug Mucuna pruriens. Phytother Res 2004;18:706-12.

14. Vamsi S, Raviteja M, Kumar GS. In-vitro antiurolithiatic potential of various extracts of Mucuna pruriens. Int J Pharm Sci Res 2014;5:3897.

15. Akhtar MS, Qureshi AQ, Iqbal JA. Antidiabetic evaluation of Mucuna pruriens, Linn seeds. J Pak Med Assoc 1990;40:147-50.

16. Sathiyanarayanan L, Arulmozhi S. Mucuna pruriens Linn. A comprehensive review. Pharm Rev 2007;1:157.

17. Sruthi T, Satyavati D, Upendar K, Kumar CP. Antidiabetic activity and anti-oxidant activity of niddwin, a polyherbal formulation in alloxan induced diabetic rats. Int J Pharm Pharm Sci 2014;6:273-7.

18. Kumar DS, Muthu AK, Smith AA, Manavalan R. In vitro antioxidant activity of various extracts of whole plant of Mucuna pruriens (Linn). Int J Pharm Tech Res 2010;2:2063-70.

19. Vadivel V, Pugalenthi M. Removal of antinutritional/toxic substances and improvement in the protein digestibility of velvet bean (Mucuna pruriens) seeds during processing. J Food Sci Technol 2008;45:242-6. 
20. Usda N. The Plants Database, Version 3.5. Baton Rouge, LA: National Plant Data Center; 2004. p. 4490-70874.

21. Acute Oral Toxicity (OECD Test Guideline 425)(AOT), 2001. Statistical pro-Gramme (AOT425StatPgm), version 1.0. Available from: http:// www.oecd.org/oecd/pages/home/displaygeneral/0,3380,EN-document524-nodirectorate-no-24-6775-8,FF.htm.

22. Krishna AB, Manikyam HK, Sharma VK, Sharma N. Acute oral toxicity study in rats with Mucuna pruriens seed extract. Asian J Plant Sci Res 2016;6:1-5.

23. Jothy SL, Zakaria Z, Chen Y, Lau YL, Latha LY, Sasidharan S, et al. Acute oral toxicity of methanolic seed extract of cassia fistula in mice. Molecules 2011;16:5268-82.
24. Shafi S, Tabassum N. Phytochemical and acute toxicity study of Eriobotrya japonica seed extract in albino mice. Int J Res Pharm Biomed Sci 2013;12:202-5.

25. Pritchett-Corning KR, Chang FT, Festing MF. Breeding and housing laboratory rats and mice in the same room does not affect the growth or reproduction of either species. J Am Assoc Lab Anim Sci 2009;48:492-8.

26. American Veterinary Medical Association (AVMA). AVMA Guidelines on Euthanasia. AVMA Animal Welfare Division; 2007. Available from: http://www.animalwelfare@avma.org.

27. Sardjono RE, Musthapa I, Qowiyah SA, Rachmawati R. Acute toxicity evaluation of ethanol extract of Indonesian velvet beans. Int J Pharm Pharm Sci 2017;9:161-5. 